\title{
中山間地における耕作放棄水田の植生遷移に 影響を及ほす要因に関する研究
}

\author{
一岐阜県恵那市における事例一
}

Factors Affecting Plant Succession in Abandoned Paddy Fields

in Mountainous Regions : Case Study in Ena City, Gifu Prefecture, Central Japan

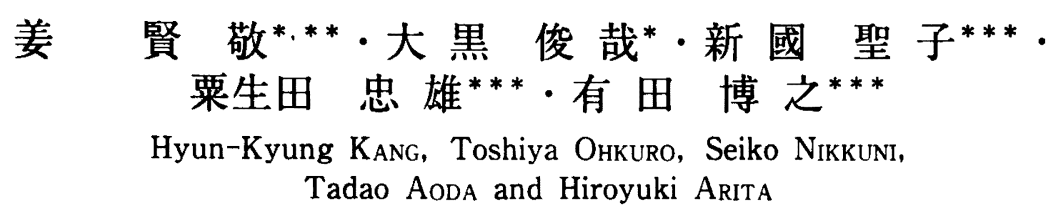

\section{I はじめに}

近年, 全国各地で急速に進む水田の耕作放棄は, 我が国の食鋉生産ポテンシャルをさらに低下させ るとともに，従来の二次的自然環境を大きく变容 させ, 水田が本来備えている各種の環境保全機能 の低下を引き起こすことが獎念されている。とり わけ中山間地では, 斜面崩壊などの自然災害の增 加や，良好な棚田景観の消失が大きな問題となっ ている。そのため, 自然環境の変化に関する詳細 な調査に基ついた，放萧水田の適正な保全・管理 方策の確立が，長期的食糧需給をふまえた農地資 源の保全および, 二次的自然環境の保全という両 方の観点から祭急の課題となっている2211。

放裹水田の環境変化は, 植生, 土壤, 地形等の 土地自然要素の変動プロセスとしてとらえること ができる。なかでも植生は，復田コストや生物相 稚持機能等の変動に直接関連するとともに23224), 土壤特性や斜面安定性の変化等, 他の自然要素の 変動指標ともなることから 21 25), 環境保全機能の 変動にかかわる紷合的な指標として有効とされて いる。たと之ば大黒ほか $(2001)^{23)}$ は放棄年数の 経過に伴う種組成・バイオマスの経時的変化を復
田や保全管理作業との関連で論じた。また有田ほ か $(2003)^{3)}$ は, 放棄年数と植生変化および復田 コストの関係をモデル化し，効果的な維持管理の 方法を提案している。

放裹水田の植生変化はこれまで，上記研究のよ うに放棄年数という時間軸との関連で整理される ことが多かった。しかし中山間地では, 傾斜地水 田が多いことはもちろん，一筆の面積が狭小なこ と, 潅排水設備が不十分であることなど, 特有の 立地特性をもつため 13 , 放棄後の植生還移はさま ざまな自然的要因による影響を受けると考えられ る。一方，耕作停止後の圃場管理もまた，悉移の 方向や速度に影響を及ほす人為的要因として位置 づけられる15)23)。こうした要因の種類や影響の程 度があらかじめ把握できれば, 精度の高い植生遷 移の予測が可能になり，放来水田の保全管理に際 して, より適切な植生指標を提示することができ ると考えられる。

そこで本研究では，中山間地の放萧水田を対象 として，放亲水田植生の遷移系列を推定したうえ で，植生遷移に影響を及は寸自然的・人為的要因 を抽出し，それらの影響を考虑した植生遷移の予 測・評価手法のあり方について検討した。

*農業渨境技術研究所 National Institute for Agro-Environment Sciences

**現・韓国祥明大学校 Sang Myung University, Korea

***新潟大学農学部 Faculty of Agriculture, Niigata University

Key Words：1)放裹水田, 2) 植生退移, 3) 中山間地，4）農地保全，5）復田コスト 


\section{II 調査地と調査方法}

\section{1 調查地の概要}

調査地として，岐皁県恵那市 I 地区を選定した。 同地区は美蕽高地南部，標高 $500 \sim 700 \mathrm{~m}$ の小起伏 山地一小起伏丘陵地に位置し, 表層地質は主に古 生層の砂岩からなる。土裹は, 水田部では主に細 粒灰色低地土壤, 周辺樹林地では褐色森林土壤 乾性褐色森林土壤が分布する7)。アメダスデータ

(恵那：標高 $315 \mathrm{~m}$ ) によれば，年平均気温は 12.8

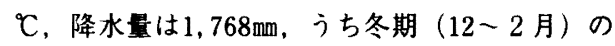
割合は $10 \%$ 程度 $(173.2 \mathrm{~mm})$ である10)。

同地域の植生は, 植物杜会学的にはヤブッバキ クラス域に属するが、ほとんどは代供植生として コナラ林, アカマッ林 (モチッッジーアカマッ群 集, ヤマツッジーアカマッ群集）が分布する16)。 また地区内にはシデコブシ自生地もあることから， 植物地理学的には東海丘陵要素の分布域に含まれ ると考えられる7゙。

\section{2 調查方法}

まず，1972年以降に撮影された空中写真の判読 により，各撮影年における水田の管理状況を把握 し、それらの休耕・放㐬年数を推定したうえで, 2002年 9 月下旬に現地踏査を行い，52固場を調查 戋場として選定した。つぎに，固場ごとの詳細な 植生調査を2002年10月中旬に行った。調査方法・ 項目は以下の通りである。現地踏査の結果, 同一 國場内でも地形的な位置により植生の状態にばら つきがみられる围場が確認された。そこで，調査 圈場ごとに，娄場中央部を通るラインを傾斜方向 に設定した上で，山側縁辺部（畦畔からおおむね $2 \mathrm{~m}$ の範囲), 中央部 (ライン上の中央点付近), 谷側縁辺部（畦畔からおおむね $2 \mathrm{~m}$ の轮囲）の 3 力所に $1 \mathrm{~m} \times 1 \mathrm{~m}$ の調查区を設定し（一部の戋場 は中央部のみ), 周囲から張り出した種を含む全 出現種の自然高 $(\mathrm{cm}, h)$ および被度 $(\%, c)$ を測定した。同時に, 調査区内のリタ一厚さ $(\mathrm{cm})$ ・被度（\%）の測定および, 土壤水分状態（乾燥， 湿潤, 湛水の定性的な 3 段階評価) ${ }^{4) 13)}$ の記載を
行った。

植生調査によって得られたデータについては，

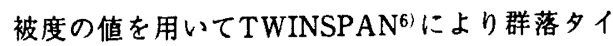
プの分類を行った。TWINSPAN分割は第 6 分割 まで行ったが, 各調査区群のサンプル数が 5 末満 となる前の段階で分割を停止した。また，調査区 ごとに，遥移度 ${ }^{18)}$, 多梯性指数 (Shanon function, $\left.H^{\prime}\right)^{9)}$, 均衡性指数 (Pielou's index of equitability, $\left.J^{\prime}\right)^{9)}$ を計算した。さらに，植物量を示す指標と して，調査区ごとに $\Sigma(h \times c)$ を計算した。上 記の計算にはPC-ORD ${ }^{12)}$ 等を用いた。

また，調查戋場を国土基本図（1：5,000）に プロットしたうえで, 各围場の地形条件を地図上 で計測した。測定項目は, 戋場幅(傾斜方向に対 する垂直方向の最大幅を測定)，傾斜（連続する 圃場をフロックとしたうえで, 各プロックの傾斜 方向の水平距離と比高から計算)，隣接斜面の傾 斜(傾斜方向に対して垂直方向に荈接する斜面に

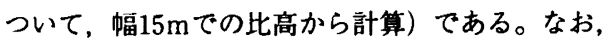
隣接斜面の傾斜は, 両側の平均値を代表値とした。

さらに，各围場の所有者に対し，過去の作付け， 水田耕作停止の時期, 水田耕作停止後の管理等に 関するアンケート調査を行った。

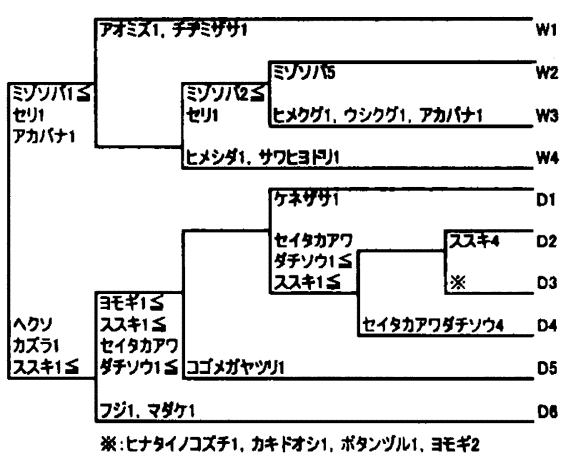

図1TWINSPANによる分割過程と分割に使用された種

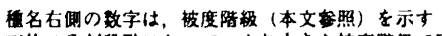

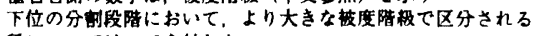
理については，ミを付した 


\section{III 調査結果}

\section{1 群落タイプの分類}

植生調查の結果, 151調查区において, 186種の 出現が確認された。まず, 調査围場における群落 タイプの特性を把握するため, 出現 2 回以上の 133 種を対象に, 全調查区の被度データを用いて TWINSPANによる分類を行った。解析に際して は, 被度を $0 \%, 10 \%, 25 \%, 50 \%, 75 \%$ で区切 ク，1〜5の階級値に変換した。

TWINSPANによる分割過程の結果を図 1 に示 す。調查区の植生は, 第 1 分割でミゾソバ・アカ バナ・セリの出現で区分される調查区群と、へク ソカズラ・ススキの出現で区分される調査区群に 区分された。土壤水分との関連をみると，前者は 乾燥状態と, 後者は湿潤・湛水状態とそれぞれ結 びつきが強い $\left(\chi^{2}\right.$ 検定, $\left.\mathrm{p}<0.001\right)$ ことから, 前者は湿性の調査区群 (以下湿性グループ), 後 者は乾性の調査区群（以下乾性タルループ）と判断
された。

湿性グループはさらに, 以下の 4 調査区群に区 分された。W $2, W 3$ はいずれもミゾソバ（被度 階級 2 以上), 七りの出現によって区分されたが, W 3 ではヒメクク, ウシクグ, アカバナ等の水田 雑草が多く出現するのに対し，W 2 ではミゾソバ が高被度（被度階級 5 ）で優占するのが特徽的で あった。一方W 4 は，ヒメシダ，サワヒヨドリの 出現によって区分され，ガマ，カサスゲ等の多年 生草本を主体とする調査区群であった。またW 4 の一部には，ミストンボ，サワギキョウ，イトイ ヌノヒゲ等, 自然性の高い湿地にみられるような 種の分布も確認された。なおW 1 は，畦畔から張 り出した木本の庇陰により林床にアオミス，千ヂ ミザサ, ヒカゲイノコズチ等の陰地性の種群が出 現する甬場であった。

乾性グループでも，主として構成種の生活型組 成により，以下の 6 調査区群に区分された。D 5 は，コゴメガヤツリの出現により区分され，メヒ シバ，エノコログサ等の一年生烟雑草が優占する 調查区群であった。これに対し多年生草本が優占

表 1 TWINSPANで区分された調査区群ごとの群落構造および塨境条件 平匀および橑整偱差（カッコ内）を示す

\begin{tabular}{|c|c|c|c|c|c|c|c|c|c|c|c|}
\hline \multirow{2}{*}{ 群营タイプ } & \multicolumn{4}{|c|}{ 家性クルーブ } & \multicolumn{6}{|c|}{ 堙性グルーブ } & \multirow{2}{*}{$p^{\bullet 1}$} \\
\hline & W1 & W/2 & W3 & W4 & D1 & D2 & D3 & D4 & D5 & D6 & \\
\hline 群藍裸 (cm) & $\begin{array}{l}134.0 \\
(42.2)\end{array}$ & $\begin{array}{l}104.8 \\
(42.6)\end{array}$ & $\begin{array}{r}73.0 \\
(43.1)\end{array}$ & $\begin{array}{l}149.5 \\
(53.8)\end{array}$ & $\begin{array}{l}201.2 \\
(77.6)\end{array}$ & $\begin{array}{l}242.4 \\
(52.9)\end{array}$ & $\begin{array}{l}180.6 \\
(79.3)\end{array}$ & $\begin{array}{l}251.1 \\
(72.7)\end{array}$ & $\begin{array}{l}80.0 \\
(7.1)\end{array}$ & $\begin{array}{c}535.0 \\
(232.2)\end{array}$ & $<0.001$ \\
\hline 佯落被度 $(\%)$ & $\begin{array}{c}73.0 \\
(11.0)\end{array}$ & $\begin{array}{c}90.2 \\
(10.1)\end{array}$ & $\begin{array}{r}72.8 \\
(25.4)\end{array}$ & $\begin{array}{r}84.5 \\
(17.8)\end{array}$ & $\begin{array}{r}85.9 \\
(19.7)\end{array}$ & $\begin{array}{l}87.4 \\
(7.4)\end{array}$ & $\begin{array}{l}91.8 \\
(5.3)\end{array}$ & $\begin{array}{c}79.4 \\
(29.1)\end{array}$ & $\begin{array}{l}74.0 \\
(4.2)\end{array}$ & $\begin{array}{l}91.5 \\
(7.1)\end{array}$ & $<0.05$ \\
\hline$\sum h \times c\left(m^{3}\right)$ & $\begin{array}{l}6.9 \\
(3.5)\end{array}$ & $\begin{array}{c}0.8 \\
(0.3)\end{array}$ & $\begin{array}{c}0.5 \\
(0.3)\end{array}$ & $\begin{array}{c}0.9 \\
(0.3)\end{array}$ & $\begin{array}{c}2.5 \\
(1.2)\end{array}$ & $\begin{array}{c}2.1 \\
(0.6)\end{array}$ & $\begin{array}{l}1.5 \\
(0.6)\end{array}$ & $\begin{array}{c}2.3 \\
(0.8)\end{array}$ & $\begin{array}{c}0.6 \\
(0.1)\end{array}$ & $\begin{array}{c}4.9 \\
(2.1)\end{array}$ & $<0.001$ \\
\hline 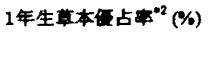 & $\begin{array}{l}1.4 \\
(1.8)\end{array}$ & $\begin{array}{c}85.8 \\
(15.5)\end{array}$ & $\begin{array}{c}56.5 \\
(25.2)\end{array}$ & $\begin{array}{r}12.9 \\
(17.6)\end{array}$ & $\begin{array}{c}5.4 \\
(9.1)\end{array}$ & $\begin{array}{c}3.6 \\
(14.7)\end{array}$ & $\begin{array}{c}19 \\
(27.8)\end{array}$ & $\begin{array}{c}2.9 \\
(3.7)\end{array}$ & $\begin{array}{l}98.9 \\
(2.1)\end{array}$ & $\begin{array}{c}0.1 \\
(0.4)\end{array}$ & $<0.001$ \\
\hline 多年生草本但占取 & $\begin{array}{r}13.7 \\
(11.7)\end{array}$ & $\begin{array}{r}13.3 \\
(15.5)\end{array}$ & $\begin{array}{l}43.4 \\
(25.2)\end{array}$ & $\begin{array}{r}77.9 \\
(20.1)\end{array}$ & $\begin{array}{c}36.4 \\
(34.7)\end{array}$ & $\begin{array}{c}78 \\
(35.4)\end{array}$ & $\begin{array}{c}77.1 \\
(27.8)\end{array}$ & $\begin{array}{l}96.3 \\
(3.8)\end{array}$ & $\begin{array}{c}1.1 \\
(2.1)\end{array}$ & $\begin{array}{c}2.7 \\
(8.4)\end{array}$ & $<0.001$ \\
\hline 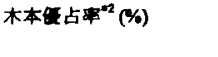 & $\begin{array}{r}84.9 \\
(11.7)\end{array}$ & $\begin{array}{c}0.9 \\
(2.2)\end{array}$ & $\begin{array}{c}0.1 \\
(0.2)\end{array}$ & $\begin{array}{c}9.2 \\
(11.4)\end{array}$ & $\begin{array}{c}58.1 \\
(34.7)\end{array}$ & $\begin{array}{c}18.3 \\
(33.7)\end{array}$ & $\begin{array}{c}3.9 \\
(5.0)\end{array}$ & $\begin{array}{c}0.9 \\
(2.5)\end{array}$ & $\begin{array}{c}0.0 \\
(0.0)\end{array}$ & $\begin{array}{l}97.2 \\
(8.8)\end{array}$ & $<0.001$ \\
\hline 出现值数 & $\begin{array}{l}12.0 \\
(2.5)\end{array}$ & $\begin{array}{c}5.8 \\
(2.7)\end{array}$ & $\begin{array}{l}12.5 \\
(2.7)\end{array}$ & $\begin{array}{l}13.7 \\
(4.0)\end{array}$ & $\begin{array}{l}10.0 \\
(3.3)\end{array}$ & $\begin{array}{c}9.5 \\
(3.2)\end{array}$ & $\begin{array}{l}10.9 \\
(2.5)\end{array}$ & $\begin{array}{l}7.7 \\
(1.8)\end{array}$ & $\begin{array}{l}11.4 \\
(2.2)\end{array}$ & $\begin{array}{c}7.4 \\
(3.9)\end{array}$ & $<0.001$ \\
\hline 多橵性指数 $\left(H^{\prime}\right)$ & $\begin{array}{c}1.61 \\
(0.26)\end{array}$ & $\begin{array}{c}0.88 \\
(0.47)\end{array}$ & $\begin{array}{c}1.77 \\
(0.29)\end{array}$ & $\begin{array}{c}1.72 \\
(0.49)\end{array}$ & $\begin{array}{c}1.36 \\
(0.46)\end{array}$ & $\begin{array}{c}0.98 \\
(0.41)\end{array}$ & $\begin{array}{r}1.56 \\
(0.34)\end{array}$ & $\begin{array}{c}0.92 \\
(0.34)\end{array}$ & $\begin{array}{c}0.99 \\
(0.27)\end{array}$ & $\begin{array}{c}0.88 \\
(0.50)\end{array}$ & $<0.001$ \\
\hline 均得性指数 $\left(J^{\prime}\right)$ & $\begin{array}{c}0.66 \\
(0.08)\end{array}$ & $\begin{array}{c}0.49 \\
(0.19)\end{array}$ & $\begin{array}{c}0.71 \\
(0.10)\end{array}$ & $\begin{array}{c}0.66 \\
(0.16)\end{array}$ & $\begin{array}{c}0.59 \\
(0.14)\end{array}$ & $\begin{array}{c}0.44 \\
(0.15)\end{array}$ & $\begin{array}{c}0.66 \\
(0.12)\end{array}$ & $\begin{array}{c}0.45 \\
(0.15)\end{array}$ & $\begin{array}{c}0.40 \\
(0.08)\end{array}$ & $\begin{array}{c}0.45 \\
(0.24)\end{array}$ & $<0.001$ \\
\hline 云移度 & $\begin{array}{l}676.5 \\
(81.7)\end{array}$ & $\begin{array}{c}262.8 \\
(337.3)\end{array}$ & $\begin{array}{l}132.0 \\
(77.4)\end{array}$ & $\begin{array}{l}515.2 \\
(360.5)\end{array}$ & $\begin{array}{l}1095.2 \\
(647.6)\end{array}$ & $\begin{array}{l}447.7 \\
(339.9)\end{array}$ & $\begin{array}{r}429.4 \\
(240.7)\end{array}$ & $\begin{array}{r}269.9 \\
(231.5)\end{array}$ & $\begin{array}{c}26.1 \\
(15.8)\end{array}$ & $\begin{array}{l}2491.8 \\
(1492.9)\end{array}$ & $<0.001$ \\
\hline リター席 (cm) & $\begin{array}{c}1.8 \\
(1.5)\end{array}$ & $\begin{array}{c}0.4 \\
(1.2)\end{array}$ & $\begin{array}{c}0.0 \\
(0.0)\end{array}$ & $\begin{array}{r}1.5 \\
(1.7)\end{array}$ & $\begin{array}{c}2.9 \\
(1.5)\end{array}$ & $\begin{array}{c}5.9 \\
(3.7)\end{array}$ & $\begin{array}{c}2.8 \\
(2.2)\end{array}$ & $\begin{array}{c}4.9 \\
(3.3)\end{array}$ & $\begin{array}{c}0.0 \\
(0.0)\end{array}$ & $\begin{array}{c}2.1 \\
(1.1)\end{array}$ & 80.001 \\
\hline リター被度 (\%) & $\begin{array}{l}46.0 \\
(34.4)\end{array}$ & $\begin{array}{r}13.3 \\
(28.7)\end{array}$ & $\begin{array}{c}0.0 \\
(0.0)\end{array}$ & $\begin{array}{c}38.3 \\
(43.9)\end{array}$ & $\begin{array}{c}63.5 \\
(34.6)\end{array}$ & $\begin{array}{c}80.2 \\
(20.6)\end{array}$ & $\begin{array}{c}56.5 \\
(32.0)\end{array}$ & $\begin{array}{l}45.0 \\
(31.6)\end{array}$ & $\begin{array}{c}0.0 \\
(0.0)\end{array}$ & $\begin{array}{r}81.5 \\
(31.0)\end{array}$ & $<0.001$ \\
\hline
\end{tabular}


する調査区群としては，D 2，D 3，D 4 が抽出 されたが，このうちD 2 はススキが，D 4 はセイ タカアワタチソウがそれぞれ高被度で優占した。 一方, 木本植物が優占する調査区群としてはD 6 が区分されたが、これらにはノリウッギ，ネコヤ ナギ等が優占する围場のほか，マタケが侵入・優 占する圈場も含まれた。またD１は，ケネザサや イタドリが高被度で優占する調査区群であった。

つぎに，TWINSPANで区分された調査区群ご とに，群落棈造を比較した（表 1)。一年生草本 の優占割合が高い調査区群は，湿性グループ（W 2 , W 3 ), 乾性ダループ (D 5) ともに, 植物 量, 選移度が低い, リターの堆積がほとんどない 等の特徵が共通して認められた。これに対し多年 生草本の優占割合が高い調查区群（W 4, D 2， D 3，D 4 ）は, 群落高, 植物量および遷移度 が高く, リターの堆積も進んでおり，とくにスス キやセイタカアワタチソウの優占する調査区群 (D 2，D 4) でその傾向が顥著であった。木本 植物の優占割合が高い調査区群 (W 1，D 1 ， D 6 ）では，群落高および遷移度がさらに高まる 傾向を示した。種多梯度 (出現種数, 多梯性指数, 均衡性指数）をみると，優占種の明瞭な調査区群 (W 2，D 2，D 4，D 6) で低くなる一方で,
W 3，W 4，D 3 などでは高い値を示した。

\section{2 群落タイプと地形条件}

国土基本図で計測した地形特性（圈場幅，傾斜， 隣接斜面の傾斜）と上記調查区群の分布との関連 性を分析した。その結果, 調査围場の傾斜はほほ $5 \sim 10^{\circ}$ の範囲にあり，調査区群間で有意な差は 認められなかった（中央值検定： p >0.05)。一 方，瀿接斜面の傾斜扔よび甬場幅は，調査区群間 で有意な差が認められ（同：それぞれ $\mathrm{p}<0.001 ）$, 乾性グループは同傾斜の緩やかな等斉型—凹型斜 面上に，また湿性タループはおおむね隣接斜面の 傾斜が急な凹型斜面上に分布する傾向が認められ た。とくにW 2 は，畨場幅が狭く，急傾斜の斜面 に囲まれた直場に多く分布する傾向を示した（図 2)。

つぎに，槏場内の地形的位置（山側縁辺部，中 央部, 谷側縁辺部) と上記調查区群の分布との関 連性についてクロス集計を行った（表 2 )。その 結果, 全体的に湿性グルーブは山側縁辺部一中央 部と, 乾性グルーブは中央部一谷側縁辺部との結 びつきが強いという傾向が認められた。とくに結 びつきが強かったのは，W 2 と山側縁辺部の関係 であった（四分点相関係数 $\phi=0.21$ )。
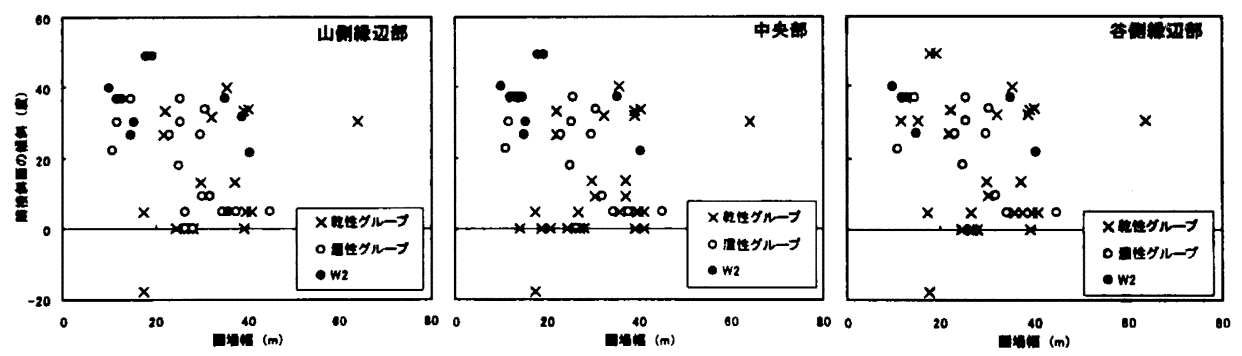

困2 TWINSPANによるクルーフことにみた闹場幅と陪斜面の傾斜との関係

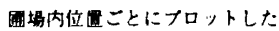

表 2 TWINSPANで区分された調査区群と围場内位量との関係

\begin{tabular}{|c|c|c|c|c|c|c|c|c|c|c|}
\hline \multirow{2}{*}{ 陆部タイプ } & \multicolumn{4}{|c|}{ 温性グループ } & \multicolumn{6}{|c|}{ 性ク゚ルーブ } \\
\hline & $W_{1}$ & W/2 & W3 & W4 & D1 & D2 & D3 & D4 & D5 & D6 \\
\hline 山回部 & $+*$ & +3 & +2 & + & -1 & -1 & -2 & - & -1 & + \\
\hline 中央部 & + & + & -2 & + & + & + & +2 & -1 & + & - \\
\hline 谷何葐辺部 & -1 & -2 & -2 & - & +1 & +1 & + & +1 & + & - \\
\hline
\end{tabular}


表 3 TWINSPANで区分された調查区群ごとの 放東年数㧍よび固場管理の状況

\begin{tabular}{|c|c|c|c|c|c|}
\hline & \multicolumn{2}{|c|}{ 故棌にたロ } & \multicolumn{3}{|c|}{ 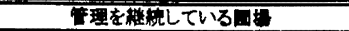 } \\
\hline & 区效 & 年敕" & 区数 & 年数 & 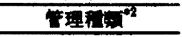 \\
\hline $\mathbf{W 1}$ & 5 & 14 & 0 & $\overline{-}$ & - \\
\hline W2 & 20 & $4 \sim 14(12)$ & 7 & $5 \sim 13(13)$ & 要刘り $(1 \sim 3)$ \\
\hline W3 & 11 & $9 \sim 24(14)$ & 9 & $9 \sim 13(13)$ & 草难D(1～3)，除豆詴 \\
\hline W4. & 12. & $12 \sim 24(15)$ & 8. & 5 & 草创? $(1 \sim 2)$ \\
\hline $\mathrm{DI}$ & 17 & $14 \sim 24(17)$ & 0 & - & - \\
\hline D2 & 15 & $4 \sim 14(9)$ & 6 & $2 \sim 12(2)$ & 部刈 $(1 \sim 2)$ \\
\hline D3 & 6 & $3 \sim 4(3)$ & 11 & $5 \sim 13(13)$ & 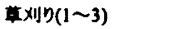 \\
\hline D4 & 6 & $14 \sim 18(18)$ & $\mathbf{0}$ & - & - \\
\hline DS & 0 & - & 5 & 12 & 草刈り(2)，䉽起 \\
\hline D6 & 10 & $13 \sim 20(20)$ & $\mathbf{0}$ & - & - \\
\hline
\end{tabular}

\section{3 群落タイプと放棄年数・管理状況}

アンケート調查の結果, 調査圃場には, 完全に 放東した國場と，耕作停止後に何らかの管理が継 続されている围場が含まれていることが分かった。 まず，完全放样した直場のみを对象として，放棄 年数を上記調査区群間で比較したところ，湿性グ ループでは, 一年生草本の優占する調査区群（W2， W 3 ) は他に比へてて放菓年数の短い圃場も含んで いたものの，中央値をみると調査区群間で大きな 差異は認められなかった。一方, 乾性グループで は，D 5 のサンブルで完全放茟の围場はなかった が，おおむねD $3<\mathrm{D} 2 ， \mathrm{D} 4<\mathrm{D} 1 ， \mathrm{D} 6$ の順 に放呆年数が長くなる傾向を示した（表 3 )。

管理状況と調査区群との関係をみると, 草刈り 管理の年数・頻度等との明瞭な関倸は認められな かったが，一年生草本の優占する調査区群（W3， D 5 ) の分布國場の一部で, 除草片施用や耕起と いった管理がなされているのが特徽的であった。 また，木本植物の優占する調查区群 (W 1，D 6 ) やケネザサ・イタドリの優占する調査区群（D 1) 等では，管理されている國場は含まれなかった (表 3)。

\section{IV 考 察}

\section{1 放衰水田植生の逗移系列の推定}

本調査地の放裹水田植生は, 種組成の特徵およ び土壤水分状態から，大きく乾性のクルーブと湿
性のグループに区分された（図 1)。耕作放裹後 の水田は一般に, 乾燥化あるいは湿潤化の方向に 進むことが知られており114)21)，本調査地域にお いても，放萧水田の植生䢬移は土壤水分状態によっ て乾性と湿性の透移系列に分かれると考えられる。 また，生活型組成からみた放菓水田植生の暧移系 列は，(1)一年生・二年生草本 $\rightarrow$ (2)多年生広葉草本 $\rightarrow$ (3)多年生1齐科草本 $\rightarrow$ (4)木本という，二次遷移 にみられる一般的な推移5)を示すことが多(202 23)。 一方，平野部を中心に多くみられるセイタカアワ タチソウの優占ステージは，本来(2)のステージに 含まれるが5)，放裹水田への侵入 ·優占時期や優 占期間1)4 202 24), 復田や管理の難易度120123) からみ ると，放杗水田の遷移系列においてはむしろ，ス スキやヨシが長期間優占する(3)のステージに位置 づけるのが適当と考えられる。したがって，本調 查地では, 組成的特徴から, W $2, W 3, D 5$ か (1)のステージに, D 3，W 4 が(2)に, W 4, D 2 , D 4 が(3)に，W 1，D 6 が(4)にそれぞれ対応する と考えられる。以上から，湿性の遷移系列として

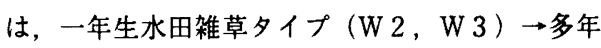
生草本夕イプ (W 4$) \rightarrow$ 木本夕イプ (W 1), 乾 性系列としては，一年生畑雑草タイプ（D 5) ～

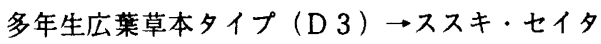

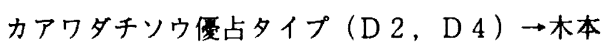
タイプ（D 6) という推移パターンが推定された。 このうち，乾性グループの(3)でススキとセイタカ アワタチソウの分布域の差異に関する要因が明瞭 でなかった点や，湿性グループの(3)でヨシが優占 しなかった点などについては，さらに詳細な検討 が必要である。またW 1 では, 畦畔植生の張り出 しが固場内植生に及は寸影響21)も考虑する必要が ある。しかし, 群落高, $\Sigma(h \times c)$ 等の植物量 を示す指標や、リター量についても，(1)から(4)の 順に增加する傾向を示しており（表 1)，上記の 系列はおおむね妥当と考えられる。

\section{2 放棄水田の植生㭡移に影䉕を及ほす要因}

以上のような植生遷移は通常, 時間軸に沿った 変化のパターンとしてとらえることができる。本 調査においても，乾性グループでは上記群落タイ プの推移と放菓年数の対応関係がある程度認めら 
れた。一方，湿性グループでは，遷移初期ステー ジに位置づけられるW 2，W 3 が，放亲後10２0 年以上経過した橉場でも維持されているなど，放 菓年数との対応が明瞭ではなかった（表 3$) 。$ 。湿 性の立地環境においては, 遷移進行の速度や還移 系列の変動が大きくなる例がしばしば報告されて おり，その要因としては，筫栄養な涌水の影锌8) や, 湛水・流水の影製132 23) 等, 地形条件に起因す る水文環境の影響が指摘されている。本調査地の 場合, 湿性グルーブの調查区群は，主として集水 域面積の大きい凹型㗔斜面19)に立地していたか， とくにミソ゚ソバの優占するW 2 は，圆場幅の狭小 な谷筋で特徵的にみられることが明らかになった （図 2 )。また個々の戒場についてみると, 漫透 水の浸出が集中しやすい山側縁辺部でW $2, \mathrm{~W} 3$ が維持されやすいことが分かった（表 2 )。松村 ほか (1988) 13)も，岐皁県山間部の休耕田におい て, 用水漂に近い過湿な場所ではミソソバの純群 落が形成されることを報告している。本調査地に おいても，地表水・浸透水等の水分環境が，一年 生草本を主体とする遷移初期群落の維持に何らか の影響を及はしていると推察される。しかしその 詳細なメカニズムについては, さらなる検討が必 要である。湿性の立地環境ではまた，逶移進行抑 制の要因として、イノシシのヌ夕場としての利用 による摚乱の影都も無視できないと考えられる。 現地の観察では, イノシシによる擋乱の痕跡が確 認された調查区は17区あり，そのうち14区が湿性 グループであった。なかでもW 3 では, 15区中 5 区でイノシシによる拱乱が認められた。今後は前 述の立地璄境とともに，こうした野生動物の行動 特性も併せた検討が必要であろう。

本調査ではまた、マタケケアケネザサの優占によ り偏向遷移が生じ, 遷移の進行が妨げられている 群落（D 1，D 6の一部）が確認された。現地の 観察では, これらのタケ・ササ類は，隣接する林 地から地下茎によって侵入しているケースが多く みられた。山間部の水田は一筆の面積が狭小で， 周囲を樹林地で囲まれている戋場が多いため13121)， 放棄後の植生遷移についても，こうした周辺植生 の影䈉を考虑する必要があると考えられる。

一方, 耕作停止後に行われる各種の圃場管理は,
遷移の進行に影響を及ほす人為的要因として位置 づけられる。調査地での主要な管理形態である草 刈りについて，前述の(1)—(3)のステージ間で比較 すると，草刈り頻度や継続年数と群落タイブとの 関係は認められなかったが, (4)のステージ（W1， D 6 ）に対応する围場では，草刈り管理は全く行 われていなかった（表 3 )。このことは，既往の 報告13115)でも指摘されてきたように, 年 1 回以上 の草刈りによって木本ステージへの移行が抑制さ れることを示唆している。また，草刚りに加え， 除草剂施用や耕起といった強度の管理を併用する ことにより，遷移初期ステージに維持することが 可能と考えられた。

\section{3 植生動態の予測に関する検討}

以上の考察により，山間部放棄水田の植生邉移 に影響を及はす放棄年数以外の要因として，水分 環境にかかわる地形条件，偏向遷移にかかわる周 辺植生の状況, 埇場管理 (方法, 頻度, 年数等) が抽出された。そこで最後にこれらの影翌を予 測するための方法について検討したい。

山間部における放棄水田植生と地形条件の関係 についてはこれまでも，地形区分に基づく遷移予 測の可能性が指摘されている21)22)。本調査の結果 からも，斜面形態を適切に区分することにより， 土壇水分環境の差異に応じた群落タイプ分布や 遷移の推定が可能と考えられた。しかし，本調査 で用いた地形図判読の方法は，精度の面では優れ ているものの，多大な労力を要する，汎用性が低 い等の問題がある。したがって, 他地域への適用 や広域スケールでの評価を行うためには，大久保 ほか（1999）191や松浦ほか (2001) 14)が提示したよ うな, 数値地形モデルの利用が有効と考えられる。

また, タケ・ササ類の侵入・優占による偏向遷 移の影響については，放育水田を直接対象とした 例はないが，竹林の分布拡大が近年西日本を中心 に問題となっていることから，その実態に関して は多くの調査がなされている。それらの報告によ れば，竹林の分布拡大速度は $2 \sim 3 \mathrm{~m} /$ 年であり， とくにオープンな場所に瀿接する場合，その拡大 速度は大きくなるとされている26)27)。そのため， 水田周辺にタケ・ササ類が分布する場合, 放棄さ 
れれば短期間でそれらが侵入・優占することが懸 念される。こうした影部を予測・評価するために は, 上記先行研究で用いられている空中写真判読 等の方法により，固場周辺でのタケ・ササ類の分 布算囲をあらかじめ把握しておくことが必要と思 われる。

以上のように，放棄水田の遷移に影響を及はす 自然的要因の把握に際しては, 地形図, 空中写真, 数値地図情報等の地理情報の活用が有効であり， これらの情報を基喽とすることにより，遷移系列 や復田コスト，生物相変動等の予測・評価への展 開が可能と考えられる。

一例として, 耕作放萧後の復田コストを予測 · 評価する場合を考えてみる。ミゾソバ等の一年生 水田雑草が優占する場合には，浅根性の群落とな るため13)，復田作業としてはプラウによる反転や ロータリーによるすき込み程度の耕起作業が中心

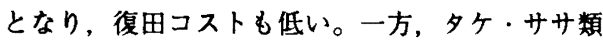
が侵入すると、チェーンソーによる伐採やバッ クホウによる除根，場合によっては農地基盤の均 平作業も必要となり, 復田コストは急敫に高ま る3) 17723)。そこで，こうした復田コストを群落夕 イプことに把暒したうえで，地理情報システムを 利用してそれぞれの群落タイプへの移行が予測さ れる围場を抽出することにより，放柈された場合 の管理の難易度や復田コストをあらかじめ評価す ることが可能となるであろう。
一方，人為的要因としては，今回のアンケート 調査により，管理形態が植生遷移に及はす影響が ある程度明らかになった。とくに，遷移初期ステー ジの調查区群は，耕起や除草刘施用によって維持 されていたことなど，管理による遷移抑制の程度 は，管理形態（種類・頻度等）によって異なるこ とが示唆された。しかし今回の調查では、こうし た管理形態と遷移抑制の関係を定量的に示すまで には至らなかった。また，人為的要因と前述の自 然的要因の影響の程度をどのように峻別するかに ついても，今後の検討課題として残された。こう した点を明らかにするためには，サンブル数を增 やす, アンケートの信頼度を高める等, アンケー 卜調查精度の改善とともに，実験的に管理の影響 を評価する等のアプローチが必要である。

以上の結果を図 3 に整理した。放棦水田の環境 変化を予測・評価し，適切な保全管理方策を検討 する際には, 現地での植生調査に加え, これらの 調査をセットで行うことで, より精度の高い植生 変化の把握および植生指標の提示が可能になると 考えられる。

\section{謝辞}

本研究は，韓国科学財団・海外ボスドク研究支援に よる研究成果の一部である。また本研究の実施にあた $\eta$, 平成14年度科学研究费補助金基䃈研究（B）を使 用した。現地調査の際には, 新潟大学農学部の学生諸

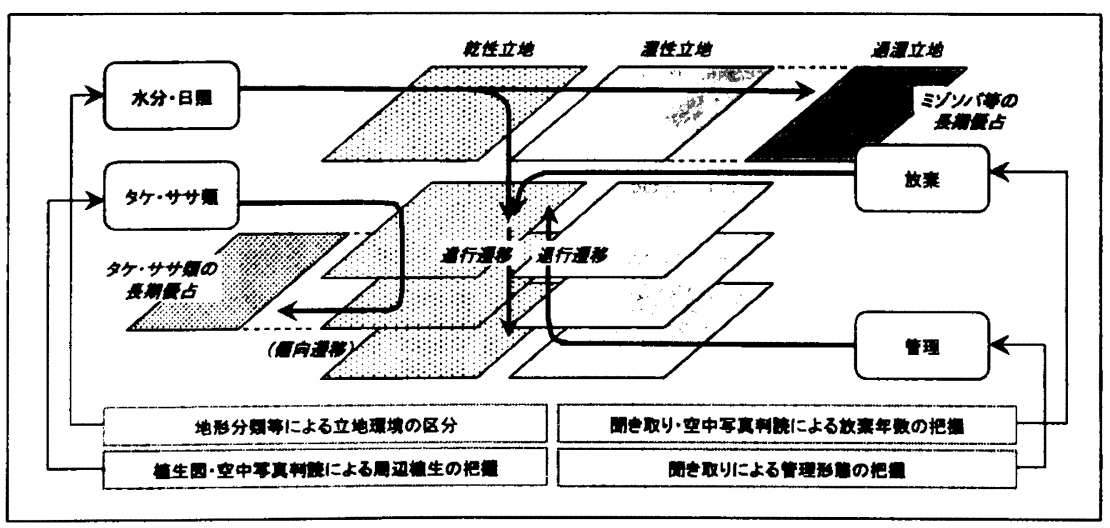

図 3 植生還移に影響を及ほす自然的・人為的要因を考虑した，放來水田植生動態の 要因把握と予測のための調査項目 
氏に多大なご協力をいただいた。記して謝意を表する。

\section{引用文嗝}

1) 安西微郎・松本直治（1988）：水田の休耕にとも なう雑草の発生状況と土境の変化. 千㷛県農試研報, 29, 93-104

2 ）有田博之·友正達美・河原秀聡（2000）: 粗放管 理による農地资源保全，農業土木学会論文集，209， 109-117.

3）有田博之・山本真由美·友正達美 · 大黒俊哉（2003） : 耕作放来水田の復田コストからみた宜地保全対策 一新潟県東顆城郡大島村を事例として一。莀業土木 学会論文集225，95-102.

4 ）箱山晋 - 田中日吉 - 䅫和一・武田友四郎 (1977)

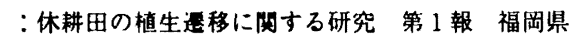
北西部地域における休耕田の植生. 日本作物学会記 事, 46, 219-227.

5 ) 林一六 (1990): 「植生地理学」. 大明堂, 東京. 6 ) Hill, M.O. (1979) : TWINSPAN, A FORTRAN program for arranging multivariate data in an ordered two-way table by classification of the individuals and attributes: Cornell University Press, Ithaca, New York.

7) 広木詔三 (2002)：「里山の生態学一その成り立 ちと保全のあり方」. 名古屋大学出版会, 名古屋.

8) 角野康郎 (1998)：中池見湿地の植物相の多粎性 と保全の意義. 日本生態学会誌, 48, 163-166.

9 ）木元新作·武田博清（1989）：「群集生態学入門」. 共立出版, 東京.

10）気象庁 (2001)：平年值 - CD-ROM版（統計期間 1971 2000年), 気象業務支援センター。

11）国土庁（1975）:土地分類図21 (岐皁県). 国土庁.

12) McCune, B. and M. J. Mefford (1999) : PC-ORD. Multivariate analysis for ecological data, version 4. MjM Software Design, Gleneden Beach, Oregon, USA.

13）松村正幸·西村伸郎·西條好迪（1988）：飛駢地 域の山間休耕田における植生退移. 日本生態学会誌, $38,121-133$.

14）松浦俊也・横張真（2001）：数値標高モデルを用い
た谷津の地形解析. 環境情報科学論文集, 15, 25-30.

15）嶺田拓也 - 石田意治 - 饭崲孝史 - 松森贸治（2003） : 中山間地における休耕田の保全管理形態と水田機 能維持のための植生指標. 2003年度農村計画学会学 術研究発表会要旨集, 27-28.

16）宮脇昭編著（1985）：「日本植生誌・中部」, 至文 堂, 東京.

17）農業土木総合研究所（2000：平成12年度農地の 維持保全手法検討調查報告竟（平成12年度農村振興 局委託業務)。農業士木総合研究所, 東京.

18）沼田页（1987）：「植物生態学論考」. 東海大学出 版会, 東京.

19）大久保悟 - 加藤好武 - 山本勝利（1999）：数値地 図情報を用いた傾斜地水田の類型化. 宸村計画論文 集， 1，289-294.

20）大黒俊哉 (2001)：休耕田・放来水田を活用した 生物多様性の保全（宇田川武俊編，「農山漁村と生 物多粎性」)，家の光協会，東京, pp. 172-188.

21）大黒俊哉・松尾和人・根本正之（1996）：山間地 における放㙌水田と畦畔のり面の植生動態. 日本生 態学会誌, 46, 245-256.

22）大黒俊哉・松尾和人・根本正之（1997）：生物多 様性保全の視点からみた中山間地の耕作放萧水田植 生一新潟県大島村を事例として一。1997年度農村計 画学会学術研究発表会諈演要旨, 145-148.

23）大黒俊哉·有田博之 - 山本真由美 - 友正達美（2001） : 中山間地域における耕作放裹水田の植生変化が復 田作業に及は寸影繁。莀村計画論文集，3，211-216.

24）大黒佼哉・白戸康人・伊藤一幸（2003）：絶隇危 惧植物タコノアシ個体群の維持にかかわる放粂水田 の環境特性. ランドスケープ研究，66(5)，599-602.

25）太田健 · 谷山一郎·草場敬 - 森昭惷 - 荒谷博 (1996) : 耕作放米棚田における土境特性の経年変化.土境 の物理性, 73, 3-10.

26）鳥居厚志（1998）：空中写真を用いた竹林の分布 拡大速度の推定一滋賀県八幡山および京都府男山に おける事例一。棟生態学会誌, 48, 37-47.

27）鳥居厚志（2002）：空中写真を用いた竹林の分布 拡大速度の推定 I一奈良県天香具山における事例一. 環境情報科学論文集, $16,375-380$.

Key Words : 1) abandoned paddy filed, 2) succession, 3) mountainous regions, 4) maintenance of agricultural land, 5) restoration cost 